\title{
The Enzymes of Ammonia Assimilation in Schizosaccharomyces spp. and in Saccharomycodes ludwigii
}

\author{
By B. JOHNSON \\ Department of Microbiology, The University, Newcastle upon Tyne NEI $7 R U$ \\ AND C. M. BROWN \\ Department of Biological Sciences, The University, Dundee DDI $4 H N$
}

(Received 27 May 1974)

\section{INTRODUCTION}

The assimilation of ammonia in many yeasts is mediated by NADP-linked glutamate dehydrogenase. The synthesis of this enzyme appears to be derepressed during growth in environments containing low concentrations of ammonia or, as in Candida utilis, where nitrate is the nitrogen source (Brown \& Johnson, I970; Burn, Turner \& Brown, 1974).

An alternative pathway, common in bacteria (Tempest, Meers \& Brown, 1973), involves the enzymes glutamine synthetase and glutamate synthase. Glutamine synthetase is widespread in yeasts, while glutamate synthase has been detected in certain Schizosaccharomyces spp. (Brown, Burn \& Johnson, I973). Roon, Even \& Larimore (1974) have reported the presence of glutamate synthase in some strains of Saccharomyces cerevisiae, together with much higher levels of both NAD- and NADP-linked glutamate dehydrogenase.

We report the results of chemostat studies on the levels of enzymes involved in ammonia assimilation in representatives of the four recognized (Lodder, I970) species of the genus Schizosaccharomyces and the single recognized species of the related genus Saccharomycodes.

\section{METHODS}

The yeast strains used in this study, Schizosaccharomyces pombe (NCYC535), Schiz. malidevorans (NCYC683), Schiz. octosporus (NCYCI31), Schiz. versatilis (NCYC4I9; recognized as Schiz. japonicus var. versatilis by Lodder, 1970), and Saccharomycodes ludwigii (NCYC730), were maintained on yeast extract $(\mathrm{I} \%, \mathrm{w} / \mathrm{v})$-peptone $(2 \%, \mathrm{w} / \mathrm{v})$-glucose $(2 \%, \mathrm{w} / \mathrm{v})$ agar and subcultured every 2 months. Batch cultures were grown in $100 \mathrm{ml}$ lots in $250 \mathrm{ml}$ flasks in an orbital shaker incubator (A. Gallenkamp \& Co. Ltd, Stockton-on-Tees, Teeside) on the 'low nitrogen' medium of Burn et al. (1974) with ammonia as nitrogen source. Chemostat cultures were grown in 0.5 or $\mathrm{I} \cdot 01$ vessels of the type described by Brown \& Rose (1969) at $30{ }^{\circ} \mathrm{C}$ and $\mathrm{pH} 4.5$ in the medium of Burn et al. (1974). Batch cultures were harvested in the late exponential phase of growth, and chemostat cultures directly from the culture vessels. Extracts were prepared as described by Brown \& Johnson (1970). The extraction and assay were done at $\mathrm{pH} 6.5$ except for the cultures of Schiz. octosporus where $\mathrm{pH} 7 \cdot 0$ was used. NAD- and NADP-linked glutamate dehydrogenase activities were assayed as described by Brown \& Johnson (1970), glutamate synthase by the method of Brown, Macdonald-Brown \& Stanley (1972) and glutamine synthetase as described by Elliott (I955). All enzyme assays were performed at $30^{\circ} \mathrm{C}$. The protein content of extracts was determined by the method of Lowry, Rosebrough, Farr \& Randall (195I). 
Table I. Influence of medium nitrogen source and concentration on the content of ammonia-assimilating enzymes in chemostat cultures

\begin{tabular}{|c|c|c|c|c|c|}
\hline \multirow[b]{2}{*}{ Organism } & \multirow[b]{2}{*}{$\begin{array}{l}\text { Growth } \\
\text { rate } \\
\left(\mathrm{h}^{-1}\right)\end{array}$} & \multirow[b]{2}{*}{$\begin{array}{l}\text { Cultural } \\
\text { condition }\end{array}$} & \multicolumn{3}{|c|}{ Enzyme (nmol/min/mg protein) } \\
\hline & & & $\begin{array}{l}\text { Glutamine } \\
\text { synthetase }\end{array}$ & $\begin{array}{l}\text { Glutamate } \\
\text { synthase }\end{array}$ & $\begin{array}{c}\text { Glutamate } \\
\text { dehydro- } \\
\text { genase } \\
\text { (NADP) }\end{array}$ \\
\hline $\begin{array}{l}\text { Schiz. pombe } \\
\text { (NCYC535) }\end{array}$ & $0 \cdot 1$ & $\begin{array}{l}\text { Ammonia limitation } \\
\text { Glucose limitation } \\
\text { Glutamate }\end{array}$ & $\begin{array}{l}\text { I I } 2 \\
\text { ND } \\
7 \cdot 3\end{array}$ & $\begin{array}{l}2 I \cdot 7 \\
15 \cdot 0 \\
19 \cdot 5\end{array}$ & $\begin{array}{l}29 \cdot 1 \\
27 \cdot 0 \\
25 \cdot 4\end{array}$ \\
\hline $\begin{array}{l}\text { Schiz, malidevorans } \\
\text { (NCYC683) }\end{array}$ & 0.1 & $\begin{array}{l}\text { Ammonia limitation } \\
\text { Glucose limitation } \\
\text { Glutamate }\end{array}$ & $\begin{array}{r}20 \cdot 7 \\
10 \cdot 4 \\
I \cdot 9\end{array}$ & $\begin{array}{l}25 \cdot 2 \\
25 \cdot 3 \\
23 \cdot 0\end{array}$ & $\begin{array}{c}28 \cdot 6 \\
25 \cdot 8 \\
\text { ND }\end{array}$ \\
\hline $\begin{array}{l}\text { Saccharomycodes } \\
\text { ludwigii }(\mathrm{NCYC} 730)\end{array}$ & 0.05 & $\begin{array}{l}\text { Ammonia limitation } \\
\text { Glucose limitation } \\
\text { Glutamate }\end{array}$ & $\begin{array}{r}16 \cdot 2 \\
13 \cdot 1 \\
6 \cdot 9\end{array}$ & $\begin{array}{l}16 \cdot 5 \\
16 \cdot 5 \\
14 \cdot 5\end{array}$ & $\begin{array}{l}27 \cdot 6 \\
44 \cdot 5 \\
32 \cdot 9\end{array}$ \\
\hline $\begin{array}{l}\text { Schiz. versatilis } \\
\text { (NCYC4I9) }\end{array}$ & 0.05 & $\begin{array}{l}\text { Ammonia limitation } \\
\text { Glucose limitation } \\
\text { Glutamate }\end{array}$ & $\begin{array}{l}41 \cdot 0 \\
24 \cdot 6 \\
13 \cdot 8\end{array}$ & $\begin{array}{l}\text { ND } \\
\text { ND } \\
\text { ND }\end{array}$ & $\begin{array}{r}269 \\
70 \cdot 6 \\
45 \cdot 4\end{array}$ \\
\hline $\begin{array}{l}\text { Schiz. octosporus } \\
\text { (NCYCI3I) }\end{array}$ & 0.05 & $\begin{array}{l}\text { Ammonia limitation } \\
\text { Glucose limitation } \\
\text { Glutamate }\end{array}$ & $\begin{array}{r}2 I \cdot 0 \\
8 \cdot 9 \\
24 \cdot 8\end{array}$ & $\begin{array}{l}\text { ND } \\
\text { ND } \\
\text { ND }\end{array}$ & $\begin{array}{l}199 \\
139 \\
206\end{array}$ \\
\hline
\end{tabular}

RESULTS AND DISCUSSION

The behaviour of batch cultures of all six organisms indicated that Schiz. pombe, Schiz. malidevorans and Saccharomycodes ludwigii contained NAD-linked glutamate synthase activity and that all the cultures tested contained NADP-linked glutamate dehydrogenase. The $\mathrm{pH}$ optimum of the glutamate synthase was in the region of 6.5 and was distinct therefore from the higher values ( $\mathrm{pH} 7 \cdot 0$ to $7 \cdot 6$ ) found in bacterial species (Meers, Tempest \& Brown, 1970; Miller, 1973) and in Saccharomyces cerevisiae (Roon et al. 1974).

Chemostat cultures were established at the growth rates shown in Table $\mathbf{I}$ and organisms were grown under conditions of ammonia limitation, ammonia excess (glucose-limited) and in the presence of glutamate (nitrogen-limited). The contents of glutamine synthetase, glutamate synthase and glutamate dehydrogenase in extracts of these cultures are detailed in Table I. The formation of glutamate synthase in Schiz. pombe, Schiz. malidevorans and Saccharomycodes ludwigii was not influenced to any marked extent by changes in the nitrogen source and concentration, nor was the synthesis of NADP-linked glutamate dehydrogenase in Schiz. pombe and Saccharomycodes ludwigii. In Schiz. malidevorans the levels of glutamate dehydrogenase were not influenced by the medium ammonia concentration and no activity was detected in extracts of cultures grown on glutamate. In Schiz. malidevorans the glutamine synthetase activity was very low in cultures grown on glutamate, while in Schiz, pombe no activity was detected on cultures grown in the presence of an excess of ammonia. The $K_{m}$ values for ammonia at $\mathrm{pH} \mathrm{6.5,} \mathrm{of} \mathrm{the} \mathrm{NADP-linked} \mathrm{glutamate} \mathrm{dehydrogenase} \mathrm{of} \mathrm{these}$ glutamate synthase-containing yeasts was of the order of $\mathrm{I} \cdot 5 \times \mathrm{IO}^{-2}$ to $2.5 \times \mathrm{IO}^{-2} \mathrm{M}$ and it is apparent that the former enzyme might not contribute significantly to ammonia assimilation unless the ammonia concentration was high. Thus, as in many bacteria, these yeasts may assimilate low or limiting concentrations of ammonia by utilizing glutamine synthetase and glutamate synthase. In the presence of an excess of ammonia, assimilation in Schiz. pombe 
would proceed via glutamate dehydrogenase since there was no detectable glutamine synthetase in cell extracts. In Schiz. malidevorans and Saccharomycodes ludwigii, however, there may be competition for ammonia between the glutamine synthetase/glutamate synthase and glutamate dehydrogenase pathways when ammonia is present in excess, unless the activity of one other of these enzymes is then modulated.

Neither the Schiz. versatilis nor the Schiz, octosporus strains used in the present study contained detectable glutamate synthase activity under the cultural conditions employed, although glutamine synthetase activity was recorded in these organisms. The behaviour of Schiz. versatilis is similar to that of other yeasts studied previously (Burn et al. 1974), in that the level of glutamate dehydrogenase activity was increased markedly by growth under ammonia limitation relative to growth with ammonia excess. This is assumed to be a mechanism compensating for the lack of glutamate synthase in these organisms. Schizosaccharomyces octosporus contained significant levels of glutamate dehydrogenase irrespective of the cultural conditions employed. Other unusual features of this organism include the fact that the $\mathrm{pH}$ optimum of the glutamate dehydrogenase was higher than in the other organisms (7.0 rather than 6.5 ) and the $K_{m}$ for 2-oxoglutarate was also higher, being $8.0 \mathrm{~mm}$ compared with values in the region of $\mathrm{I} \cdot 0 \mathrm{~mm}$.

The results presented above indicate that ammonia assimilation during ammonia limitation in cultures of Schiz. pombe, Schiz. malidevorans and Saccharomycodes ludwigii proceeds via glutamine synthetase and glutamate synthase, and it is noteworthy that none of these organisms synthesized increased levels of glutamate dehydrogenase under these conditions. The findings of Roon et al. (1974) differ from the present results in that the Saccharomyces cereviseae strains studied showed glutamate synthase activity together with much higher levels of NAD- and NADP-glutamate dehydrogenase. However, these workers did not assay glutamine synthetase activity and no firm conclusion can be reached about the possible role of the glutamine synthetase/glutamate synthase pathway in this organism. The level of glutamate synthase did not vary greatly in any of the organisms under the conditions studied, a similar finding having been made by Roon et al. (1974) using batch cultures in $S$. cerevisiae. We suggest that the exent to which the dual enzyme pathway contributes to ammonia assimilation is a function of the cell content and activity of glutamine synthetase.

These findings also demonstrate that the genus Schizosaccharomyces is particularly heterogeneous with respect to ammonia assimilation.

\section{REFERENCES}

Brown, C. M., Burn, V. J. \& Johnson, B. (1973). Presence of glutamate synthase in fission yeasts and its possible role in ammonia assimilation. Nature New Biology 246, i $15-16$.

Brown, C. M. \& Johnson, B. (1970). Influence of the concentration of glucose and galactose on the physiology of Saccharomyces cerevisiae in continuous culture. Journal of General Microbiology 64, 279-287.

Brown, C. M., Macdonald-Brown, D. S. \& STanley, S. O. (1972). Inorganic nitrogen metabolism in marine bacteria: nitrogen assimilation in some marine pseudomonads. Journal of the Marine Biological Association of the United Kingdom 52, 793-804.

Brown, C. M. \& Rose, A. H. (1969). Effects of temperature on composition and cell volume of Candida utilis. Journal of Bacteriology 97, 261-272.

Burn, V. J., Turner, P. R. \& Brown, C. M. (1974). Aspects of inorganic nitrogen assimilation in yeasts. Antonie van Leeuwenhoek 40, 93-102.

Elliott, W. H. (1955). Glutamine synthesis. In Methods in Enzymology, vol. 2. Edited by S. P. Colowick and N. O. Kaplan. New York: Academic Press.

Lodder, J. (1970). The Yeasts - A Taxonomic Study, 2nd edn. Amsterdam: North Holland Publishing.

Lowry, O. H., Rosebrough, N. J., Farr, A. L. \& Randall, R. J. (I95I). Protein measurement with the Folin phenol reagent. Journal of Biological Chemistry 193, 265-275. 
Meers, J. L., Tempest, D. W. \& Brown, C. M. (1970). Glutamine(amide): 2-oxoglutarate amino transferase oxido reductase (NADP), an enzyme involved in the synthesis of glutamate by some bacteria. Journal of General Microbiology 64, 187-194.

MiLler, R. E. (1973). Glutamate synthase from Escherichia coli: an iron-sulphide flavoprotein. In The Enzymes of Glutamine Metabolism. Edited by S. Prusiner and E. R. Stadtman. New York: Academic Press.

Roon, R. R., Even, H. L. \& LARIMORE, F. (I974). Glutamate synthase: properties of the reduced nicotinamide dinucleotide-dependent enzyme from Saccharomyces cerevisiae. Journal of Bacteriology Ir8, $89-95$.

Tempest, D. W., Meers, J. L. \& Brown, C. M. (1973). Glutamate synthase (GOGAT); a key enzyme in the assimilation of ammonia by prokaryotic organisms. In The Enzymes of Glutamine Metabolism. Edited by S. Prusiner and E. R. Stadtman. New York: Academic Press. 